\title{
PREVENTION OF NEWBORN SKIN LESIONS: KNOWLEDGE OF THE NURSING TEAM ${ }^{1}$
}

\author{
Simone Vidal Santos ${ }^{2}$, Roberta Costa
}

\begin{abstract}
${ }^{1}$ Extract from the thesis - Guide to prevention and treatment of skin lesions in newborns admitted to the Neonatal Intensive Care Unit: a collective construction of the nursing team, presented at the Programa de Mestrado Profissional em Gestão do Cuidado em Enfermagem, at the Universidade Federal de Santa Catarina (UFSC), in 2014.

${ }^{2}$ Master in Nursing Care Management. Nurse-Enterostomal Therapist at the University Hospital of UFSC. Florianópolis, Santa Catarina, Brazil. Email: simonevidal75@gmail.com

${ }^{3}$ Ph.D. in Nursing. Professor of the Departamento de Enfermagem of UFSC. Florianópolis, Santa Catarina, Brazil. Email: robertanfr@ hotmail.com
\end{abstract}

\begin{abstract}
A qualitative study was conducted using a convergent care approach, whose aim was to identify the knowledge of the neonatal nursing team about the prevention of skin lesions in hospitalized newborns. This study was conducted in the neonatal unit of a hospital in southern Brazil with 14 nursing professionals. Data were obtained through semi-structured interviews performed in November and December 2012. Data analysis was through apprehension, synthesis, theorization and a recontextualization processes. The results show nursing professionals are aware of newborn skin particularities, recognizing the need for skin protection, body temperature regulation, transepidermal water loss, and proper hygiene. The team also recognized the need for hydration and proper handling, as well as the need for precautions in invasive procedures, prevention of pressure and puncture lesions, care in device fixation and use of antiseptics. The results of this study demonstrated the need for providing sensitive and risk-free care, thus promoting comfort and safety for these patients.
\end{abstract}

DESCRIPTORS: Nursing care. Skin. Infant, newborn. Neonatology. Prevention.

\section{PREVENÇÃO DE LESÕES DE PELE EM RECÉM-NASCIDOS: O CONHECIMENTO DA EQUIPE DE ENFERMAGEM}

\begin{abstract}
RESUMO: Estudo qualitativo do tipo pesquisa convergente-assistencial, com objetivo de identificar o conhecimento da equipe de enfermagem neonatal sobre prevenção de lesões de pele em recém-nascidos internados. Realizado na unidade neonatal de um hospital do Sul do Brasil com 14 profissionais de enfermagem. Os dados foram obtidos através de entrevistas semiestruturadas realizadas em novembro e dezembro de 2012. A análise se deu através dos processos de apreensão, síntese, teorização e recontextualização. Os resultados indicam que os profissionais têm ciência das particularidades da pele do recém-nascido, reconhecendo a necessidade de cuidados com a proteção da pele, regulação térmica, perda de água transepidérmica, higiene, hidratação e manuseio, além dos cuidados com procedimentos invasivos, prevenção de lesões por pressão e punção, cuidados na fixação dos dispositivos e uso de antissépticos. Evidencia-se com este estudo a necessidade de se realizar um cuidado delicado, livre de riscos, promovendo conforto e segurança a estes pequenos pacientes.
\end{abstract}

DESCRITORES: Cuidados de enfermagem. Pele. Recém-nascido. Neonatologia. Prevenção.

\section{PREVENCIÓN DE LESIONES DE LA PIEL EN RECIÉN NACIDOS: CONOCIMIENTOS DEL EQUIPO DE ENFERMERÍA}

\begin{abstract}
RESUMEN: Investigación cualitativa, convergente asistencial, con el objetivo de identificar los conocimientos del personal de enfermería neonatal en la prevención de lesiones en la piel de los recién nacidos. Se realizó en un hospital en el sur de Brasil, con 14 enfermeras. Los datos fueron recolectados a través de entrevistas semi-estructuradas en noviembre y diciembre de 2012. El análisis se realizó mediante aprensión, síntesis, teorización y recontextualización. Los resultados indican que el profesional es consciente de las particularidades de la piel del recién nacido, reconociendo la necesidad de la protección, regulación térmica, pérdida de agua transepidérmica, la higiene, la hidratación y la manipulación. Además de la atención con los procedimientos invasivos, prevención de úlceras por presión y punción, cuidado en la fijación de los dispositivos y uso de antissépticos. A partir de este estudio se percibe la necesidad de realizar cuidados delicados, libre de riesgo, proporcionando seguridad a estos pacientes.
\end{abstract}

DESCRIPTORES: Atención de enfermería. Piel. Recién nacido. Neonatología. Prevención. 


\section{INTRODUCTION}

Skin is the largest organ of the human body and it has several functions: it acts as a barrier to water loss and effects of irritants, provides thermoregulation and infection control as well as immunosurveillance and tactile sensation. The main skin layers are: epidermis, dermis and hypodermis. The outermost layer of the skin is in the epidermis, called stratum corneum, and this is the main barrier to water loss and penetration of external agents. ${ }^{1}$

The structural integrity of the stratum corneum is related to the gestational age at birth, and the barrier is quickly developed in 24 to 34 weeks after birth. At that point, the skin structure of a full-term newborn is similar to that of adults, whereas a preterm newborn has a significantly thinner epidermis and poorly formed stratum corneum. Consequently, a preterm newborn's skin may have lesions and its high permeability may cause high water loss, electrolyte imbalance, distermia and greater exposure to room irritants and infectious agents. ${ }^{1}$

In addition, hospitalization in a neonatal unit and the various procedures and handling involved in neonate care may cause skin lesions and infection in newborns, considerably contributing to increased morbimortality in this population. ${ }^{2}$ In this group, pressure lesions, shearing, lacerations, traumas, burns, chemical irritation, drug extravasation, incontinency and infections are the most frequent occurrences. ${ }^{3}$

Although a challenge to neonatal unit professionals, maintaining skin integrity, especially of preterm newborns, should be a priority during newborn care, as it helps increase the chances of survival of these patients. ${ }^{4}$ However, for the development, implementation and improvement of skin integrity maintenance proposals, the multidisciplinary team should participate as a group. New practices can be developed when the team recognizes the need for proper care for newborns and newborn skin handling, as well as the limits of every intervention. ${ }^{5}$ In this context, the nursing team has an important role in neonate care, as such care is planned and supervised by nurses and performed by both nurses and other professionals. $^{6}$
Nurses acting as investigators in a neonatal unit of a hospital in southern Brazil, have witnessed concerns on the part of the nursing team about the skin care of hospitalized neonates. Nursing professionals are often insecure, especially about the use of topical agents. There are standard actions taken in skin lesion prevention and the team often needs guidance in such actions. The lack of guidance may lead to lesions and require a longer healing time, as they necessitate frequent changes in nurse conduct, which does not allow continuity of care and causes insecurity in the team members. This situation encouraged some exploration of this topic, and resulted in the formulation of the following question: what is the knowledge of the nursing team about skin lesion prevention in hospitalized newborns? Therefore, to develop nursing care focused on skin lesion prevention, it is important to identify the challenges of the nursing team while providing this care. The purpose of this study was to identify the knowledge of the nursing team about skin lesion prevention in newborns hospitalized in a neonatal unit.

\section{METHOD}

This study is a qualitative convergent-care research. The purpose of a convergent-care research is to find out ways to resolve or minimize problems and to make changes and suggest innovation in practice. This type of investigation considers the need to relate theory and practice while building nursing knowledge. ${ }^{7}$

Data from this study were obtained from semi-structured interviews, with a set of openand closed-ended questions related to participant identification and length of service in neonatal units, as well as questions related to skin care of newborns hospitalized in this unit.

The study was conducted at the neonatal unit of a hospital in southern Brazil, a midsize public institution linked with the Ministry of Education. It has 16 beds distributed in four rooms: one room is a neonatal intensive care unit (NICU), one room is a conventional neonatal intermediate care unit, one room is for kangaroo neonatal intermediate care and the last one is an isolation room. 
The study participants were nursing professionals from the neonatal unit handling hospitalized newborns. The nursing team, during data collection, was comprised of six nurses, 12 nursing technicians and eight nursing assistants. The inclusion criterion was: nurses must be working in the data collection period. Nurses on vacation, maternity leave or sick leave were excluded from the study.

In total, four nursing assistants, six nursing technicians and four nurses participated in the study. They were invited for the interview during working hours, which was conducted in a reserved area to ensure privacy. Data collection was concluded when the investigator realized the information obtained was repeated, not providing new understanding to the investigation and showing data saturation. ${ }^{8}$

Data were collected in November and December 2012. The interviews were recorded and the participants signed an informed consent term and an authorization to record the interviews. The study observed the ethical principles of Resolution 196/96 of the National Health Council. ${ }^{9}$ The study was approved by the Research Ethics Committee of the Federal University of Santa Catarina, under protocol 34574/2012. The study subjects were identified with flower names to ensure anonymity.

At first, the analysis involved the apprehension process, through interview transcription and data reading, and defining key words according to the study purpose. Then, the synthesis process was conducted, which involved a deeper reading of data, allowing greater familiarity with information and when common data were grouped, resulting in the definition of codes, which in turn helped define the categories. Then, theorization was applied via interpretation of categories based on the literature, producing the final considerations of the study. Finally, recontextualization was conducted through data socialization. ${ }^{7}$

\section{RESULTS AND DISCUSSION}

The participants of this study were mostly female subjects $(92.8 \%)$. Their age ranged from 25 to 55 years, with more than half the number of participants over 40 years of age $(64.3 \%)$. Regarding their school education level, seven people had concluded high school (50\%) and seven had concluded higher education (50\%). Of these, five had a master's degree (35.7\%). Most participants had performed activities in the institution's neonatal unit for over ten years $(64.3 \%)$. The interview duration was six to 20 minutes.

Based on data collected two categories were defined. These categories explain the thoughts of the nursing team from the neonatal unit regarding lesion prevention in hospitalized newborns. They were "Newborn skin has its own particularities" and "Invasive procedures and use of devices affect skin integrity".

\section{Newborn skin has its own particularities}

Soon after birth, a newborn starts to adapt to extrauterine life. This period may be complex, as newborns, previously in a warm, wet, sterile and safe uterine environment, have to adapt to a cool and dry environment, full of bacteria, and requiring some conditions to survive, such as breathing, enteral nutrition, temperature regulation and water balance maintenance. ${ }^{1,10}$

After breathing stabilization, the most urgent need of a newborn is thermoregulation, essential to newborn survival, considering that cold stress may lead to hypoxia, metabolic acidosis and hypoglycemia. Heat production involves the neurological, cardiovascular and metabolic systems, placing a preterm newborn at a disadvantage, since these systems are not fully developed at birth. ${ }^{11}$

In addition, newborns may lose heat through evaporation, radiation, convection and conduction. In preterm newborns, heat loss through evaporation, or transepidermal water loss (TWL), is about 10 times greater than in full-term newborns. ${ }^{11-13}$

Preterm newborns' epidermis is thinner, and their stratum corneum is not fully developed, in contrast to a fully developed layer in full-term newborns. This leads to higher cutaneous permeability and, consequently, increases the preterm newborn's exposure to environmental irritants and infectious agents. ${ }^{1,11-12}$

In this study, nursing professionals showed they were aware that specific care for skin lesion prevention is required. The testimonial below shows the neonatal nursing team knew newborn's 
skin specificities, highlighting some precautions to prevent lesions:

[...] a newborn's skin is very sensitive, less thick, thinner and, depending on the situation, it will require moistening, proper temperature and special care that, sometimes, is not for adults [...], a newborn's skin has its own particularities [...] (Hibiscus).

[...] very sensitive, fragile, we have to pay attention, because of its sensitivity, any movement, pressure, some glue, something, it's not as resistant as an adult skin [...] (Saffron).

[...] the first care is no temperature oscillation [...] (Bromelia).

According to the literature, ${ }^{1,11-12}$ the skin of preterm newborns has particularities that may severely affect their life. Frequent handling required in a neonatal unit makes the first 12 hours critical for thermal stabilization.

[...] first care is no temperature oscillation[...] is a quote by Bromelia. To help newborn thermoregulation, the nursing team can use strategies such as putting a cotton cap on the newborn's head to reduce heat loss through the cephalic region, and placing the newborn in a polyurethane bag to reduce heat loss through evaporation. ${ }^{13}$

Other resources are heat cradles and incubators, technologies to keep a neutral thermal environment for the preterm newborn, and incubators with moistening which help reduce thermal instability and evaporative loss, indicated for newborns weighing less than 1,000 $\mathrm{g}$ and whose gestational age is less than 30 weeks. ${ }^{13}$ The concern about newborn care regarding moistening is also seen in the testimonials of participants:

[...] in incubator, for preterm newborns, we use moistening to keep the temperature and protect the skin [...] (Dahlia).

[...] we use the moistening incubator at birth, as it keeps the skin moistened, and it's better for the newborn [...] (Begonia).

Another practice reported by nursing professionals and that should be questioned is the bath, particularly for preterm newborns. A bath may lead to hypothermia, vital sign instability, breathing discomfort and high oxygen consumption. ${ }^{12,14}$

[...] the bath, which has been reduced, and I guess that was important, because it's one less aggression to the newborn skin, whenever we gave them a bath they used to take longer to recover heat, until they reached stabilization again [...] (Dahlia).

[...] bath is important, it's been determined recently that bath is not necessary every day, but on Mondays, Wednesdays and Fridays. [...] reducing bath improves skin $\mathrm{pH}$ and gives protection [...] (Carnation).

At birth, a neonate's skin presents neutral $\mathrm{pH}$, becoming physically acid $(\mathrm{pH}<5.5)$ after a few days. This skin acidification process creates the acid mantle, contributing to improved cohesion and integrity of the stratum corneum and reducing the barrier permeability. However, in preterm newborns, the acid mantle development may take several weeks, leaving the skin unprotected against bacteria, injuries and absorption of topical agents. ${ }^{11,14}$

Daily baths and the use of soaps may affect the acid mantle development, increasing the skin $\mathrm{pH}$; in addition, it may cause skin irritation and dry skin. Hence, daily baths and soaps should not be encouraged. The baby can be bathed in water only, twice to three times a week. ${ }^{11-12,14-15}$

Just like baths, hygiene in the area covered by diapers was also a concern for the nursing team, as reported by the interviewee below:

[...] the biggest lesions are associated with perianal hyperemia and integrity affected due to excessive antibiotics, which causes frequent evacuation and we see diaper change every three hours [according to the institution's practice] is not enough or the attention given [...] (Viola Tricolor).

Diaper dermatitis is a serious problems in newborns. It occurs due to skin occlusion by the diaper, with consequent contact of the skin with urine and stool, converting urea into ammonia through bacterial action, which in turn destroys the acid mantle and produces alkaline cutaneous $\mathrm{pH}$. It activates fecal enzymes, proteases and lipases and degrades proteins and lipids of the stratum corneum, leading to skin tear and damaging the barrier function. ${ }^{12,16-17}$

One of the risk factors for dermatitis is the use of antibiotics, which alters stool consistency and with the use of diapers, favors the occurrence of dermatitis. ${ }^{18}$ The interviewees showed that they were aware of the cause for dermatitis, but were also unsure about any preventive actions. 
[...] I don't know if that is allergy to diapers or anything like that [...] I don't know if dermatitis is due to antibiotics or diaper, but we have it there, although we take care [...] (Yellow Rose).

[...] skin rash is another lesion we have there [...] we try to prevent skin rash, but sometimes the baby has diarrhea [...] (Hibiscus).

To prevent diaper dermatitis, some of the precautions are routine skin inspection, use of disposable superabsorbent diapers, diaper changes every three/four hours or as soon as they become dirty, smooth cleaning of perineum with warm water and cotton but no soaps, ${ }^{19}$ as well as perineal skin care with products that preserve or restore elasticity and the ideal barrier function. ${ }^{12,16,20}$

A preterm newborn's skin has an inefficient epidermal barrier. The use of emollients reduces the frequency of dermatitis, prevents dry skin and skin fissures, reduces transepidermal water loss (TWL) and improves skin integrity. ${ }^{19}$

To foster skin hydration, promote epidermal barrier function and prevent lesions, the nursing team recognized the action of emollients consisting of essential fatty acids (EFA) in newborn care, as reported by the interviewees below:

[...] For premature babies, we have special care after the bath, using EFA on all body for hydration [...] (Viola Tricolor).

Emollients are emulsions with lipids that smoothen and restore skin elasticity, homeostasis and prevent TWL. It should be applied right after a bath, on wet skin. Perfumed emollients should be avoided as they may cause sensitization and irritation. ${ }^{19,21}$ However, the routine use of emollients is not a consensus in worldwide neonatal units. Cochrane's review published in 2003 associated the use of this product in the two first weeks of life with increased risk of infection caused by coagulase-negative Staphylococcus epidermidis. ${ }^{22}$ On the other hand, a controlled randomized study conducted in 2006 did not find an increased infection rate when comparing preterm newborns in therapy with or without emollients. ${ }^{23}$ Based on the studies above, the Association of Women's Health, Obstetric and Neonatal Nurses (AWHONN) $)^{15}$ maintains that emollients help protect and preserve the epidermal barrier and can be used on newborn skin.
However, it recommends attention to infection while using these products.

Although the practices mentioned so far are essential for newborn skin integrity maintenance, the interviewees highlight handling as the basic precaution for safe and efficient care, as reported below:

[...] depending on the baby prematurity, when it's a very fragile baby, I always compare it to a balloon, very thin, almost transport, we can see the veins under the skin, it's very sensitive. Any touch, anything more aggressive can injure the skin (Begonia).

The testimonial above shows the need to carefully handle newborns to prevent lesions. In addition, newborns perceive and recognize the world through the skin, and for this reason, proper newborn touching, although a challenge to the nursing team, is responsible for the quality of life of these patients. ${ }^{5}$

This category showed nursing professionals identified newborn skin specificities and fragilities, and they highlighted important practices in the care of this population. They recognized that the actions performed by nursing professionals since the moment newborns are hospitalized make the difference in skin lesion prevention.

\section{Invasive procedures and use of devices affect skin integrity}

In a neonatal unit, several technological devices and invasive procedures are essential for neonate life maintenance. Endotracheal tubes, catheters and nasal prongs, intravenous infusion devices and feeding tubes are some of the items used by the nursing team to provide care. ${ }^{24}$ The use of these devices, combined with the physiological conditions present, predisposes newborns to skin lesions and, consequently, to infections. ${ }^{2}$

Newborns hospitalized in neonatal units are at risk of developing pressure ulcers, particularly preterm newborns, who have limited mobility and immature epidermis, and many times, improper nutrition. ${ }^{25}$ The use of various medical devices, such as oxygen tubes, mechanical ventilation and catheters, have been identified as causes of pressure lesions. ${ }^{26}$ Over $50 \%$ of pressure ulcers in newborns are related to these devices. ${ }^{25}$ These lesions do not occur only on bone saliences, they can occur in unusual 
regions, such as ears, nose and the abdomen. ${ }^{27}$ The testimonial below showed that the use of devices generated concerns about skin care for hospitalized newborns:

[...] check for anything that can harm and injure the skin, such as poorly placed bed sheets, hydration caps that sometimes can stay with the baby [...] the skin sensor, if not well placed, a very tight venous puncture fixation, it injures the skin [...] (Jasmine).

Newborn care in neonatal units requires a careful inspection of risk areas with regard to devices. These devices should be regularly inspected. ${ }^{25}$ In addition, special mattresses, frequent supine change and protectors under the devices are some recommended precautions to prevent pressure ulcer in newborns. ${ }^{12}$

Regarding medical devices, another aspect to be considered refers to fixation. Tapes placed on thin and fragile newborn skin, especially their removal, can easily cause skin injury. ${ }^{28}$ In preterm newborns, placing and removing tapes may cause extensive skin lesions. ${ }^{12}$ The testimonial below indicates that the nursing team took precautions when using these tapes:

[...] For a nasal tube fixation, then we use hydrocolloid dressing. The size of the hydrocolloid dressing, sometimes the premature baby is so small that the dressing is large and when the tube is removed, even with hydrocolloid dressing, it causes a skin lesion, depending on how the baby is removed from that [...] (Viola Tricolor).

Viola Tricolor's report showed that the nursing team was concerned about device application and fixation to the newborn skin. It also showed that some professionals use non-recommended practices in the neonatal unit, such as the inadequate tape type, size and incorrect removal.

To prevent newborn skin lesion, the use of fixation tape should be limited and discriminate. Tape should be carefully removed, with gauze moistened in a saline solution or mineral oil, allowing no trauma in removal. , $15,24^{2}$

The use of hydrocolloid, polyurethane, silicone dressings, among others, may be an alternative to protect skin from device pressure and prevent lesions from tape removal. They reduce trauma and should be placed between the skin and the device, constituting a skin protection barrier. $5,15,24$
Among the invasive procedures used on hospitalized newborns, venous and arterial punctures are of great concern to the nursing team. Possible hematomas, drug extravasation and phlebitis are mentioned by the interviewees, as follows:

In puncture, we watch it frequently, there's no routine, we analyze how it is, if it has hyperemia, if the solution has not leaked out, if Abocath ${ }^{\circledR}$ is not loosen, well in puncture, it's basically that. If there is hyperemia, we see if one more puncture is required or not (Carnation).

[...] sometimes, even a correct puncture for sample collection has blood extravasation, it has caused a hematoma, even before you make a compression, but there are some precautions to take [...] (Viola Tricolor).

Regarding punctures for fluid or drug administration, complications are hematomas, bloodstream infection caused by catheter, thrombosis, phlebitis, infiltration, extravasation and hemorrhage. ${ }^{29-31}$

Drug extravasation is the most common adverse event in neonates. ${ }^{32}$ On the other hand, a study conducted in a neonatal unit of a public maternity ward in Rio de Janeiro showed that the most common lesion was infiltration $(79.2 \%)$, followed by phlebitis (16.7\%) and extravasation $(4.2 \%){ }^{33}$ These studies ${ }^{32-33}$ agree with the testimonials of the nursing team interviewed for this study, who indicated challenges in the prevention of hematomas, phlebitis and extravasation.

To prevent lesions due to puncture, AWHONN ${ }^{15}$ recommends the use of silicone catheters, avoiding punctures in places of difficult immobilization, device fixation with transparent dressing for proper visibility of the insertion site and adjacent areas and proper solutions for infusion in peripheral venous access. These practices can reduce complications related to these procedures.

Proper asepsis of skin surface is essential for the prevention of infections and it should be performed before any invasive procedure. This practice uses skin disinfectants; the most common skin disinfectants are isopropyl alcohol, aqueous or alcoholic chlorhexidine gluconate (CHG) and povidone-iodine. ${ }^{15}$ Although these disinfectants have been tested for effectiveness, the selection of the best product for newborn skin has been widely discussed and this topic generated doubts 
and concerns in the nursing team, as seen in the report below:

[...] we are analyzing these routines about using aqueous chlorhexidine on preterm newborn skin, and among the professionals, nurses and physicians, there's a discussion, even in the medical team, about what to use [...] (Viola Tricolor).

Immature stratum corneum and skin barrier function of preterm newborns may favor increased skin disinfectant absorption through the skin. The skin disinfectant selection for extremely premature babies is a dilemma for the health team, as these products may cause chemical burns. ${ }^{15}$ In addition, iodine-based products can also alter the thyroid gland function. ${ }^{34}$

In a randomized controlled study that compared the topical use of aqueous chlorhexidine $1 \%$ with povidone-iodine $10 \%$ with relation to the blood culture contamination rates in newborns, CHG was more effective than povidone-iodine; in addition, no occurrence of contact dermatitis was reported in this study. ${ }^{35}$

Isopropyl alcohol is not recommended as a primary skin disinfectant. All skin disinfectants should be fully removed from newborn skin with a saline solution as soon as the procedure is concluded. ${ }^{15}$

According to the testimonials in this study, the nursing team had concerns about products that could be used in newborn skin asepsis, and also these professionals knew how to identify the necessary care required during invasive procedures and how to use devices to prevent lesions in this population.

\section{CONCLUSION}

The purpose of this study was to identify the nursing team's knowledge about the prevention of lesions on newborn skin in a neonatal unit. However, the findings went beyond this purpose, as they also showed the quality of care provided by the interviewed professionals. In their testimonials, they showed their awareness of newborn fragility and displayed a constant concern about improving their care.

This study indicated nursing professionals recognized the specificity of newborn skin since they highlighted important practices for the pre- vention of skin lesions. The findings confirmed that the interviewees knew it was necessary to protect the newborn skin through thermoregulation maintenance, TWL prevention, hygiene practices, skin hydration and proper handling. They also recognized the need to take precautions in invasive procedures and in the use of devices, through prevention of pressure and puncture lesions, precautions in device fixation and use of skin disinfectants.

The study demonstrated that the chief nurse should constantly mobilize the team, ensuring a connection among the team members and a better understanding of their potential, seeking to ensure standardized and improved care. This would help effect the necessary changes in nursing practices.

The findings of this study will be the starting point for the development of a convergentcare study, whose purpose is to create a guide of nursing care for the prevention and treatment of newborn skin lesions, using a process of collective collaboration. Consequently, it is important to identify the knowledge of every participant.

Scientific studies about specific newborn skin care are scarce in the literature. Hence, new studies should be conducted on this topic to confirm the practices of the neonatal nursing team.

Finally, the testimonials in this study regarding the precautions needed to prevent skin lesions in hospitalized newborns, highlighted the need for providing sensitive and risk-free care and promoting the comfort and safety of these patients.

\section{REFERENCES}

1. Visscher MO. Update on the use of topical agents in neonates. Newborn Infant Nurs Rev. 2009 Mar; 9(1):31-47.

2. Rolim KMC, Barbosa RMA, Medeiros RMG, Leite ML, Gurgel EPP. Permanência da membrana semipermeável na pele do recém-nascido: um cuidado diferenciado. Rev Rene. 2010 Jan-Mar; 11(1):144-51.

3. Fox MD. Wound care in the neonatal intensive care unit. Neonatal Netw. 2011 Sep-Oct; 30(5):291-303.

4. Stadiskoski MFS, Perin T. O cuidado com a pele do recém-nascido prematuro. Rev Enferm Atual. 2010; 10(58):23-7.

5. Martins CP, Tapia CEV. A pele do recém-nascido prematuro sob a avaliação do enfermeiro: cuidado 
norteando a manutenção da integridade cutânea Rev Bras Enferm. 2009 Set-Out; 62(5):778-83.

6. Conselho Federal de Enfermagem (COFEN). Decreto n. 94.406, de 08 de junho de 1987. Regulamenta a Lei n. 7.498, de 25 de junho de 1986, que dispõe sobre o exercício da Enfermagem, e dá outras providências. COFEN [Internet] 08 jun 1987 [acesso 20 Jul 2013]. Disponível em: http:/ / www.cofen.gov. br/decreto-n-9440687_4173.html

7. Trentini M, Paim L. Pesquisa convergenteassistencial: um desenho que une o saber fazer e o saber pensar na prática assistencial em saúdeenfermagem. $2^{\mathrm{a}}$ ed. Florianópolis (SC): Insular; 2004.

8. Fontanella BJB, Ricas J, Turato ER. Amostragem por saturação em pesquisas qualitativas em saúde. Cad Saúde Pública. 2008 Jan; 24(1):17-27.

9. Ministério da Saúde (BR). Resolução nº196/1996. Dispõe sobre pesquisa envolvendo seres humanos. Bioética. 1996; 4(2 Supl):5-25.

10. Viera CS, Mello DF. O seguimento da saúde da criança pré-termo e de baixo peso egressa da terapia intensiva neonatal. Texto Contexto Enferm. 2009 Jan-Mar; 18(1):74-82.

11. Hockenberry MJ. Wong, fundamentos de enfermagem pediátrica. $8^{\mathrm{a}}$ ed. Rio de Janeiro (RJ): Elsevier; 2011.

12. Ness MJ, Davis DMR, Carey WA. Neonatal skin care: a concise review. Int J Dermatol. 2013 Jan; 52(1):14-22.

13. Ministério da Saúde (BR). Secretaria de Atenção à Saúde, Departamento de Ações Programáticas e Estratégicas. Atenção à saúde do recém-nascido: guia para os profissionais de saúde - Cuidados com o recém-nascido pré-termo. Brasília (DF): MS; 2011.

14. Jackson A. Time to review newborn skincare. Infant. 2008; 4(5):168-71.

15. Association of Women's Health, Obstetric and Neonatal Nurses (AWHONN). Neonatal skin care: evidence-based clinical practical guideline. $3^{\text {rd }}$ ed. Washington, DC (US); 2013.

16. Cooper P. Skin care: managing the skin of the incontinent patient. Wound Essentials. 2011; 6: 69-74.

17. Rotta $\mathrm{O}$, coordenador. Guia de dermatologia: clínica, cirúrgica e cosmiátrica. Barueri (SP): Manole; 2008.

18. Fernandes JD, Machado MCR, Oliveira ZNP. Fisiopatologia da dermatite da área das fraldas: Parte I. An Bras Dermatol. 2008; 83(6):567-71.

19. Fernandes JD, Machado MCR, Oliveira ZNP. Prevenção e cuidados com a pele da criança e do recém-nascido. An Bras Dermatol. 2011; 86(1):10210.

20. Beeckman D, Woodward S, Gray M. Incontinenceassociated dematitis: step by step prevention and treatment. Br J Community Nurs. 2011 Aug; 16(8):382-9.
21. Oliveira ZNP, organizador. Dermatologia pediátrica. Barueri (SP): Manole; 2009.

22. Conner JM, Soll RF, Edwards WH. Topical ointment for preventing infection in preterm infants. Cochrane Database Syst Rev. 2004; (1):CD001150.

23. Beeram M, Olvera R, Krauss D, Loughran C, Petty M. Effects of topical emollient therapy on infants at or less than 27 weeks' gestation. J Natl Med Assoc. 2006 Feb; 98(2):261-4.

24. Rolim KMC, Farias CPX, Marques LC, Magalhães FJ, Gurgel EPP, Caetano JÁ. Atuação da enfermeira na prevenção de lesão de pele do recém-nascido. Rev Enferm UERJ. 2009 Out-Dez; 17(4):544-9.

25. Razmus I, Lewis L, Wilson D. Pressure ulcer development in infants: state of the science. J Healthc Qual. 2008; 30(5):36-42.

26. European Pressure Ulcer Advisory Panel and National Pressure Ulcer Advisory Panel. Prevention and treatment of pressure ulcers: quick reference guide. National Pressure Ulcer Advisory Panel [online]. 2009 [acesso 2013 Jun 04]. Disponível em: http://www.epuap.org/guidelines/QRG_ Prevention_in_Portuguese.pdf

27. Black JM, Cuddigan JE, Walko MA, Didier LA, Lander MJ, Kelpe MR. Medical device related pressure ulcers in hospitalized patients. Int Wound J. 2010; 7(5):358-65.

28. Körner A, Dinten-Schmid B, Stoffel L, Hirter K, Käppeli S. Skin care and skin protection in preterm babies. Pflege. 2009 Aug; 22(4):266-76.

29. Mccallum L, Higgins D. Care of peripheral venous cannula sites. Nurs Times. 2012; 108(34-35):12-5.

30. Wu J, Mu D. Vascular catheter-related complications in newborns. J Paediatr Child Health. 2012 Feb; 48(2):E91-5.

31. Ministério da Saúde (BR). Secretaria de Atenção à Saúde, Departamento de Ações Programáticas Estratégicas. Atenção à saúde do recém-nascido: guia para os profissionais de saúde - Intervenções comuns, icterícia e infecções. $2^{\mathrm{a}}$ ed. Brasília (DF): MS; 2013.

32. Sardesai SR, Kornacka MK, Walas W, Ramanathan $R$. Iatrogenic skin injury in the neonatal intensive care unit. J Matern Fetal Neonatal Med. 2011 Feb; 24(2):197-203.

33. Gomes ACR, Silva CAG, Gamarra CJ, Faria JCO, Avelar AFM, Rodrigues EC. Assessment of phlebitis, infiltration and extravasation events in neonates submitted to intravenous therapy. Esc Anna Nery. 2011 Jul-Sep; 15(3):472-9.

34. Araújo BBM, Esteves SX, Cardoso ES, Meirelles JNL, Dias CMB. A enfermagem e (des)cuidados com a pele do prematuro. Rev Pesqui Cuid Fundam. 2012 Jul-Set; 4(3):2679-91.

35. Nuntnarumit $P$, Sangsuksawang N. A randomized controlled trial of $1 \%$ aqueous chlorhexidine 
gluconate compared with $10 \%$ povidone-iodine for topical antiseptic in neonates: effects on blood culture contamination rates. Infect Control Hosp Epidemiol. 2013 Apr; 34(4):430-2. 